\title{
Transmission Studies on an Indian Isolate of Cowpea Mosaic Virus
}

\author{
S. Surekha*, S.J. Magar, P. Satyadev and V. Prasanna Krishna \\ College of agriculture, latur, VNMKV, Parbhani, Maharashtra, India \\ *Corresponding author
}

\begin{abstract}
A B S T R A C T
\section{Keywords}

CpMV (Cowpea Mosaic

Virus), Aphid

transmission, Non persistent

\section{Article Info}

Accepted:

04 May 2018

Available Online:

10 June 2018

An Indian isolate of Cowpea mosaic virus (CpMV) was found easily transmitted under glass house conditions by mechanical sap inoculation, using $0.1 \%$ potassium phosphate buffer (pH 7.4). Symptoms of mechanical transmission were characterized by mosaic, veinal necrosis, vein clearing, vein banding, blistering, stunting, leaf deformations, chlorosis and cupping of leaves. Three Aphid species viz. Myzus persaicae, Aphis Gossypii, and Aphis craccivora were found successfully transmitted the Cpmv from plant to plant. Acquisition feeding period of 40-60 seconds was found enough to acquire virus with maximum transmission of $73.3 \%$ by Myzus persicae. The virus was also found to be transmitted by seed and noticed high disease incidence $(37.1 \%)$ with seeds collected from mechanically inoculated plants, than seeds collected from healthy seed lot $(18.5 \%)$. Thus the virus under study was seed borne and sap transmissible, and it was also transmitted by Aphid vector in a non-persistent manner.
\end{abstract}

\section{Introduction}

Cowpea (Vigna unguiculata L. Walp) is one of the World's important dicotyledonous leguminous food crops of millions of people in the developing countries (Summerfield et aI., 1974).

Worldwide cowpeas are cultivated in approximate 8 million hectares. The total world production was estimated to be about 3.3 million tonnes of dry grain. Area under cowpea in India was 3.9 million hectares with a production of 2.21 million tonnes with the national productivity of $683 \mathrm{~kg} \mathrm{ha}^{-1}$ (Singh et al., 2012). Major states growing cowpea are Maharashtra, Karnataka, Tamilnadu, Madhya Pradesh, Rajasthan and Andhra Pradesh. In
Maharashtra, cowpea occupies an area of 11 , 800 ha with an average productivity of $400 \mathrm{~kg}$ $\mathrm{ha}^{-1}$ (Anonymous, 2012). Many factors contribute to very low yields and diseases are the ones responsible for reduction in cowpea yield. Among these viral diseases are major constraints to production and yield (Bashir and Hampton, 1996). More than 20 viruses affect cowpea production Worldwide (Thottappilly and Rossel, 1985).

Yield losses of almost $90 \%$ or even total crop failure have been reported (Kaiser and Mossahebi, 1975; Raheja and Leleji, 1974). Considering the economic losses caused by the virus the present investigations were carried out in the glass house during 2015 at college of agriculture, Latur. 


\section{Materials and Methods}

\section{Source of inoculum}

Virus infected vegetable cowpea (Vigna unguiculata spp unguiculata) cv. Pusa Phalguni plants through the seed provided initial inoculum. Subsequently it was maintained and multiplied on cv. Pusa Phalguni through aphid and mechanical transmission and was used for different studies.

Healthy test plants of cowpea cv. Pusa Phalguni were raised in earthen pots containing steam-sterilized soil, compost and sand (2:1:1) mixture. All the transmission tests were carried out at primary leaf stage. All the inoculated plants were maintained in an insect free glass house and observations on the aspects like incubation period, percentage infectivity and symptoms were recorded.

\section{Transmission studies}

\section{Mechanical transmission}

For mechanical transmission, sap was extracted by crushing symptomatic leaves of cv. Pusa Phalguni cultivar of vegetable cowpea with a mortar and pestle in a chilled $0.05 \mathrm{M}$ potassium phosphate buffer $\left(\mathrm{P}^{\mathrm{H}} 7.4\right)$ containing $0.02 \mathrm{M}$ 2-mercapto ethanol. Test plants were inoculated by conventional leaf rub method with a cotton swab. Carborandum (800 mesh) was used as an abrasive. Immediately after virus inoculation, the leaves of test plants were rinsed with tap water. Test plants used for mechanical inoculation were raised from virus free seeds in earthen pots containing steam sterilized soil, sand and compost (2:1:1) mixture. Test plants were maintained in an insect-free glass house for 46 weeks and observations were recorded with respect of symptom development and incubation period.

\section{Aphid transmission}

For aphid transmission, Aphis craccivora Koch. Aphis gossypii Glov, and Myzus persicae Sluz, raised from single aphid colony were used. For raising an aphid colony, the healthy leaves of cotton (Gossypium hirsutum L.) and groundnut (Arachis hypogea L.) were placed in a petridishes on slightly wet filter paper and an apterous form of aphids were transferred separately with small camel hair brush to the leaves. Petridishes were closed for 8 hours and the newly born aphids were used for transmission studies. The apterous forms of aphids were transferred to clean petridishes for 2 hours fasting. This was followed by an acquisition feeding of 40 to 60 seconds on virus infected detached leaves of source plant.

Aphids were allowed to make only brief probes of 40 to 60 seconds duration. Aphids still in probing position at 40 seconds were picked up with camel hair brush and transferred in batches of 25 to healthy test plants for inoculation feeding of four hours. The test plants were kept in muslin cages. Later, aphids were killed by spraying with 0.02 percent imidacloprid (17.8 EC) insecticide and plants were maintained in an insect free glass house for three to four weeks. Observations were recorded for the symptoms on test plants. The healthy seedlings receiving non viruliferous aphids served as control.

\section{Seed transmission}

For seed transmission, the seeds were collected from the virus infected cowpea test cultivars. Seeds were sown in earthen pots containing steam sterilized soil, sand and compost (2:1:1) mixture and maintained in an insect free glass house. Observations were recorded for percent transmission and the plants with perceptible symptoms were counted in total population for determining the level of transmission. 


\section{Results and Discussion}

\section{Mechanical transmission}

The results on sap inoculation indicated that, the virus was readily transmitted by mechanical means from infected cv. Pusa Phalguni to uninfected cv. Pusa Phalguni. The systemic symptoms produced by mechanical inoculation on cv. Pusa Phalguni of cowpea were fine vein clearing (Fig. 1) and veinal necrosis which were evident on first trifoliate leaves after 8 to 10 days of virus inoculation. This was followed by interveinal chlorosis and green vein banding on second and third trifoliate leaves apparently evident after 18 days of virus inoculation. Irregular mosaic (Fig. 2), cupping (Fig. 3) and puckering along with the main central vein (Fig. 4) were evident on subsequent trifoliate leaves after 21 to 25 days of virus inoculation. The systemic symptoms produced by the virus upon mechanical inoculation on cv. Pusa Phalguni of cowpea were similar to those produced by seed transmission on the same cultivar.

Similar result regarding sap transmission was reported earlier by Gahukar and Kalore, (1984); Sekar and Sulochana, (1986); Damiri et al., (2013).

\section{Aphid transmission}

The results on aphid transmission of cv. Pusa Phalguni of cowpea virus is shown in Table 1 and graphically in Figure 5. It is revealed from the table, that the virus was transmitted by three aphid species in the non-persistent manner from infected cv. Pusa Phalguni to uninfected cv. Pusa Phalguni. These aphids included Aphis craccivora, A. gossypii and Myzus persicae. Of these aphids, Myzus persicae was found to be the most efficient vector. The Aphis craccivora and A. gossypii were next in order for their efficiency in transmitting the seed borne virus of cv. Pusa
Phalguni. Aphids picked up the virus from seed borne plants showing vein clearing and chlorotic vein banding symptoms and transmitted it to the healthy test plants of $\mathrm{cv}$. Pusa Phalguni of cowpea.

Similar results of aphid transmission was reported earlier by Bock, (1973); Bashir et al., (2002); Anitha and Nandihalli, 2008); Kitajima et al., (2008); Damiri et al., (2013) and Santoshi et al., (2015).

From Table 2, it is revealed that transmission efficiency of aphid transmissible virus infecting cowpea by Myzus persicae and Aphis craccivora was found to be dependent on the number of aphids used/test plant. When 1, 5, 10, 15 and 20 Aphids/test plants were used the per cent transmission obtained was $0 \%, 30 \%$, 40\%, 60\% and 75\%, respectively by Myzus persicae and $0 \%, 20 \%, 30 \%, 50 \%$ and $70 \%$ per cent respectively by Aphis craccivora. $80 \%$ transmission was obtained in both the cases by using 25 aphids, respectively. The systemic symptoms produced on cv. Pusa Phalguni of cowpea by aphid inoculation were similar to those produced on same cultivar by sap inoculation and plants infected through seeds.

Similar results regarding transmission efficiency of Aphis craccivora and Myzus persicae was earlier reported by Syed, (1988).

\section{Seed transmission}

The studies revealed that, seed transmission of virus in commercial seeds of cv. Pusa Phalguni was found to vary from 17.6 to 19.2 per cent in two tests conducted separately. On an average, seed transmission of commercial seed was found to the extent of $18.5 \%$. However, no significant reduction in percentage seed germination was found in commercial seed of cv. Pusa Phalguni of cowpea. 
Table.1 Aphid transmission of a virus infecting cowpea cv. Pusa Phalguni

\begin{tabular}{|c|c|c|c|c|c|c|c|}
\hline \multirow{3}{*}{$\begin{array}{l}\text { Sr. } \\
\text { No. }\end{array}$} & \multirow{3}{*}{ Test aphid } & \multirow{3}{*}{$\begin{array}{l}\text { No. of } \\
\text { aphids/plant }\end{array}$} & \multirow{3}{*}{ Virus source* } & \multirow{3}{*}{$\begin{array}{l}\text { Test } \\
\text { plants }^{* * *}\end{array}$} & \multirow{3}{*}{$\begin{array}{l}\text { Per cent } \\
\text { Transmission }\end{array}$} & \multicolumn{2}{|c|}{ Reaction $* * * *$} \\
\hline & & & & & & \multicolumn{2}{|c|}{ cv. Pusa Phalguni } \\
\hline & & & & & & Local & Systemic \\
\hline 1. & Aphis craccivora & 20 & $\begin{array}{l}\text { cv. Pusa Phalguniof } \\
\text { cowpea with vein } \\
\text { clearing symptoms on } \\
\text { primary leaves }\end{array}$ & $21 / 30$ & $70.0 \%$ & - & $\mathrm{Vc}, \mathrm{Vb}, \mathrm{M}$ \\
\hline 2. & A. gossypii & 20 & -do- & $18 / 30$ & $60.0 \%$ & _ & $\mathrm{Vc}, \mathrm{Vb}, \mathrm{M}$ \\
\hline 3. & Myzus persicae & 20 & -do- & $22 / 30$ & $73.3 \%$ & - & $\mathrm{Vc}, \mathrm{Vb}, \mathrm{M}$ \\
\hline
\end{tabular}

$*=c v$. Pusa Phalguni of cowpea with seed transmitted symptoms on primary leaves.

** = cv. Pusa Phalguni of cowpea: no. of plants with disease symptoms/total no. of plants inoculated with the virus

$* * *=\mathrm{Vc}=$ Vein clearing; $\mathrm{Vb}=$ Vein banding; $\mathrm{M}=$ Mosaic; $-=$ Test plants not infected.

Table.2 Efficiency of Myzus persicae and Aphis craccivora vectors in transmitting the virus infecting cowpea (cv. Pusa Phalguni)

\begin{tabular}{|c|c|c|c|c|c|c|c|}
\hline \multirow{2}{*}{$\begin{array}{l}\text { Sr. } \\
\text { No. }\end{array}$} & \multirow{2}{*}{$\begin{array}{l}\text { No. of } \\
\text { aphids/ } \\
\text { plant }\end{array}$} & \multicolumn{3}{|c|}{ Aphis craccivora } & \multicolumn{3}{|c|}{ Myzus persicae } \\
\hline & & $\begin{array}{l}\text { No. of plants } \\
\text { inoculated }\end{array}$ & $\begin{array}{c}\text { No. of plants } \\
\text { with } \\
\text { symptoms }\end{array}$ & $\begin{array}{c}\text { Transmission } \\
(\%)\end{array}$ & $\begin{array}{l}\text { No of plants } \\
\text { inoculated }\end{array}$ & $\begin{array}{c}\text { No. of plants } \\
\text { with } \\
\text { symptoms }\end{array}$ & $\begin{array}{c}\text { Transmission } \\
(\%)\end{array}$ \\
\hline 1. & 1 & 20 & 0 & 0 & 20 & 0 & 0 \\
\hline 2. & 5 & 20 & 4 & 20 & 20 & 6 & 30 \\
\hline 3. & 10 & 20 & 6 & 30 & 20 & 8 & 40 \\
\hline 4. & 15 & 20 & 10 & 50 & 20 & 12 & 60 \\
\hline 5. & 20 & 20 & 14 & 70 & 20 & 15 & 75 \\
\hline 6. & 25 & 20 & 16 & 80 & 20 & 16 & 80 \\
\hline
\end{tabular}

$\mathrm{Cv}=$ Cultivar 
Fig.1 Cowpea leaves showing vein clearing

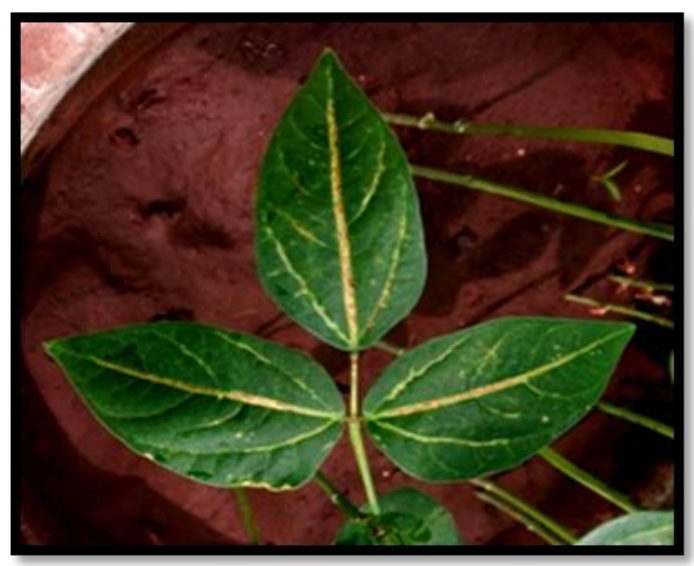

Fig.2 Cowpea leaves showing irregular mosaic

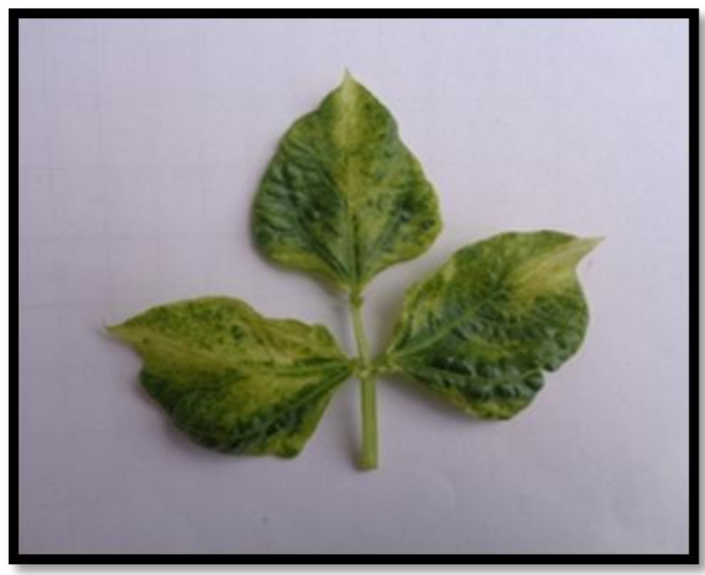

Fig.3 Cupping of leaf

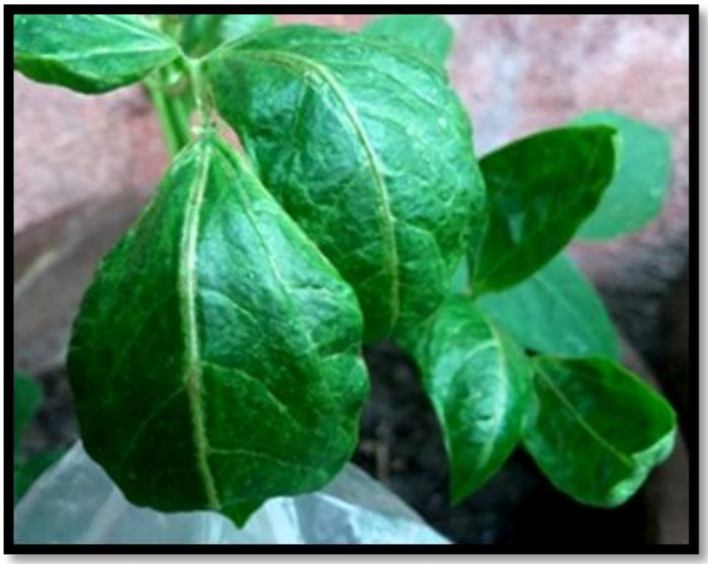

Fig.4 Puckering of cowpea leaves along the central vein

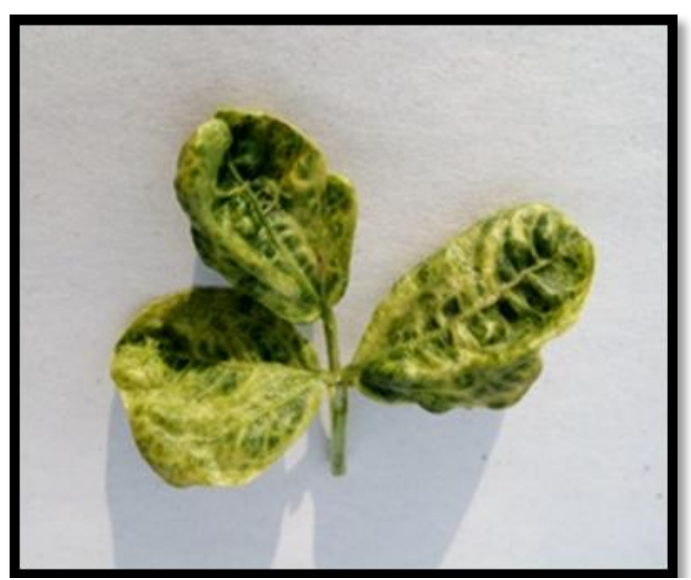

Fig.5 Per cent transmission of aphid transmissible virus infecting cowpea by three aphid species

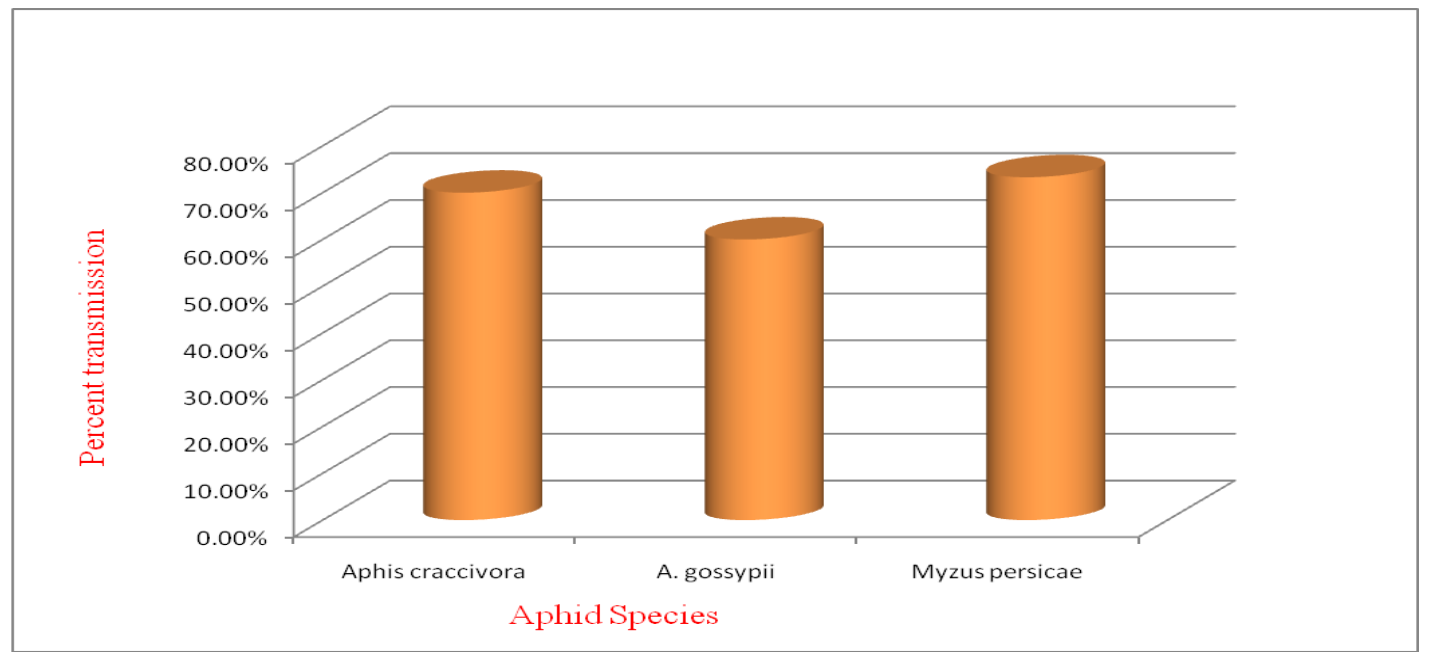


On the other hand, the seed transmission was found to be at higher level when seed was collected from mechanically inoculated plants, on first trifoliate leaves than from commercial seed. In case of mechanically inoculated plants the seed transmission ranged from 36.3 to 41.9 per cent in three tests conducted independently. The average seed transmission was up to the extent of 37.1 per cent. Similarly, the reduction in seed germination was found to be varying from 17.3 to 8.3 per cent with an average of $12.5 \%$. Results also indicated that, disease incidence was high $(37.1 \%)$ in seeds collected from mechanically inoculated plants than commercial seed (18.5\%).

Similar results on seed transmission were reported earlier by Syed, (1988); Tsuchizaki et al., (1970); Bock and Conti, (1974); Neya et al., (2007); Damiri et al., (2013) and Neya et al., (2013). Neya et al., (2013) also assessed disease incidence percentage in virus free seeds and seeds contaminated with virus and reported that, propagation of cowpea mosaic caused by CABMV was low with varieties having low ability of virus transmission by seed in particular with virus free seeds or seeds slightly contaminated.

Symptoms on experimental field and mechanical transmission were characterized by mosaic, veinal necrosis, vein clearing, vein banding, blistering, stunting, leaf deformations, chlorosis and cupping of leaves. Similar result regarding sap transmission was reported earlier by Gahukar and Kalore (1984), Sekar and Sulochana (1986) and Damiri et al., (2013).

The results on aphid transmission revealed that, cowpea aphid transmissible virus was transmitted by three aphid species in the nonpersistent manner from infected Pusa Phalguni cultivar to uninfected Pusa Phalguni cultivar. These aphids included Aphis craccivora, A. gossypii and Myzus persicae. Of these aphids Myzus persicae was found to be the most efficient vector. The Aphis craccivora and $A$. gossypii were next in order for their efficiency in transmitting the seed borne virus of cv. Pusa
Phalguni. Similar results of aphid transmission was reported earlier by Bock (1973), Bashir et al., (2002), Anitha and Nandihalli (2008), Kitajima et al., (2008), Damiri et al., (2013) and Santoshi et al., (2015).

The results of seed transmission revealed that, the average per cent transmission of aphid transmissible virus infecting cowpea in commercial seed and in seeds collected from mechanically inoculated plants was $18.5 \%$ and $37.1 \%$, respectively. Results also indicated that, disease incidence was high $(37.1 \%)$ in seeds collected from mechanically inoculated plants than commercial seed (18.5\%). Similar results on seed transmission were reported earlier by Syed, (1988); Tsuchizaki et al., (1970); Bock and Conti, (1974); Neya et al., (2007); Damiri et al., (2013) and Neya et al., (2013). Neya et al., (2013) also assessed disease incidence percentage in virus free seeds and seeds contaminated with virus and reported that, propagation of cowpea mosaic caused by CABMV was low with varieties having low ability of virus transmission by seed in particular with virus free seeds or seeds slightly contaminated.

Based on symptamatology and transmission studies present virus under study was similar to cowpea aphid borne mosaic virus or black eye cowpea mosaic virus. Some workers regarded BICMV and CABMV are closely related or synonymous with each other (Bock and Conti 1974; Taiwo et al., 1982).

\section{References}

Anitha, K.R. and Nandihalli, B.S. (2008). Utilization of botanicals mycopathogens in the management of sucking pests of okra, Karnataka J. Agril Sci. 21 (2): 231233.

Anonymous, (2012). FAO Bulletin of Statistics, Statistics Division of Economics and Social Department. 2: 54.

Bashir, M. and Hampton, R.O. (1996). Detection and identification of seedborne viruses from cowpea (Vigna 
unguiculata (L.) Walp) germplasm. $P l$. Pathol. 45: 54-58.

Bashir, M., Ahmad, Z. and Ghafoor, A. (2002). Cowpea aphidborne mosaic potyvirus: A Review Intern. J. of Pest Manag.48: 155168.

Bock, K.R. (1973). East African strains of Cowpea aphid-borne mosaic viruses Ann. Appl. Biol. 74:175-183.

Bock, K.R. and Conti. M. (1974). Cowpea aphid-borne mosaic virus. CMI/AAB., Description of Plant Viruses No. 134.

Damiri, B.V., Al-Shahwan, I.M., Al-Saleh, O.A., Abdalla, O.A. and Amer, M.A. (2013). Identification and characterization of Cowpea aphid-borne mosaic isolates in Saudi Arabia. J. Pl. Path. 95(1): 79-85.

Gahukar, K.B. and Kalore, A.R. (1984). Mosaic disease of cowpea in Vidarbha. PKV. Res. J. 8(2): 44-47.

Kaiser, W.J. and Mossahebi, G.H. (1975). Studies with Cowpea aphid-borne mosaic virus and its effect on cowpea in Iran. FAO Pl. Prot. Bull. 23: 33-39.

Kitajima, E.W., de Alcantara, B.K., Madureira, P.M., Alfenas- Zerbini, P.J., Rezende, A.M. and Zerbin, F.M. (2008). A mosaic of beach bean (Canavalia rosea) caused byanisolate of Cowpea aphid-borne mosaic virus (CABMV) in Brazil. Archives. Virol. 153: 743-747.

Neya B.J., Zida, P.E. and Oumar, T. (2013). Effect of insecticide treatments and seed qualityon the control of cowpea aphid borne mosaic disease. Europ. J. Exp. Biol. 3(6): 370-381.

Raheja, A.K. and Leleji, O.I. (1974). An aphidborne mosaic disease of irrigated cowpea in Northern Nigeria. Pl. Dis. 58: 10801084

Santoshi, T., Pudake, Mina, D., Koche, Y. N. and Mohod. (2015). Study on host range, physical properties and transmission of cowpea mosaic virus (CPMV). Universe of Emerging Tech. and Sci. 2(4): Impact Factor: 0.272 .

Sekar, R. and Sulochana, C.B. (1986). Host range of black eye cowpea mosaic virus.Current Sci. India. 55 (23): 12021203.

Singh, A.K., Bhatt, B.P., Sundaram, P.K., Santosh, K., Bahrati, R. C., Naresh, C. and Mathura, R. (2012). Study of site specific nutrients management of cowpea seed production and their effect on soil nutrient status. J. Agric. Sci. 4(10): 191198.

Summerfield, R.J., Huxley, P.A. and Steele, N.N. (1974). Viruses infecting cowpea (Vigna unguiculata (L.) Walp.). Field Crop Abstr.27: 301-312.

Syed quadari M.S.A (1988). Studies on seed borne aphid transmissible virus infecting cowpea (Vigna unguiculata (L.) Walp.) M.Sc. Thesis, MAU, Parbhani.

Taiwo, M.A., Gonsalves, D., Provvidenti, R. and Thurston, H.O. (1982). Partial characterization and grouping of isolates of Blackeye cowpea mosaic and Cowpea aphid-bornemosaic viruses. Phytopath. 72: 590-596.

Thottappily, G. and Rossel, H. W. (1985). World-wide occurrence and distribution of virus diseases. In S. R. Singh and K. O. Rachie (Eds.), Cowpea Research, Production and Utilization: 155-171). John Wiley and Sons, Chichester, UK.

Tsuchizaki, T., Yora, K. and Ashyama, H. (1970). The virus causing mosaic of cowpea and ajuki bean and transmissibility through seeds. Ann. Phytopath. Soc. of Japan. 36: 112-120.

\section{How to cite this article:}

Surekha, S., S.J. Magar, P. Satyadev and Prasanna Krishna, V. 2018. Transmission Studies on an Indian Isolate of Cowpea Mosaic Virus. Int.J.Curr.Microbiol.App.Sci. 7(06): 528-534. doi: https://doi.org/10.20546/ijcmas.2018.706.060 